\title{
Oroxylin A attenuates cytokines in neonatal asthmatic mice by regulating Notch signaling pathway
}

\author{
Ping Hua, Wei Wang, Lina Xiao, Hongjie Tao* \\ Department of Pulmonary and Critical Care Mediline, Tonglu First People's Hospital, Tonglu, Hangzhou, Zhejiang province, \\ China, 311500 \\ *For correspondence: Email: huaping1984@163.com; Tel/Fax: 0086-0571-64399695
}

\begin{abstract}
Purpose: To investigate the protective effect of oroxylin A against neonatal asthma in mice. Methods: Asthma was induced in P12 mice with ovalbumin (OVA) immediately after litter (day 0), and on day 14 of protocol. Oroxylin A was given daily in two doses (2 and $10 \mathrm{mg} / \mathrm{kg}$, i.p.) from day 0 to 14,2 $h$ before the administration of OVA. The protective effect of oroxylin A against asthma was determined by evaluating lung function and levels of cytokines and IgE in OVA-challenged mice. Moreover, Western blot assay and quantitative real-time polymerase chain reaction (qRT-PCR) were used to determine the effect of oroxylin A on Notch signaling pathway in OVA-challenged mice.

Results: Oroxylin A improved lung function in OVA-challenged mice. There were significant $(p<0.01)$ reductions in levels of IgE and cytokines in the BALF of oroxylin A-treated group, when compared to OVA group of mice. Furthermore, treatment with oroxylin A significantly ameliorated the OVA-induced changes in protein expressions of Notch1, Jagged1, NICD, PTEN, PI3K and Akt in the CD+cells of OVA-challenged mice $(p<0.01)$.

Conclusion: These results indicate that oroxylin A improves lung function and reduces the level of cytokines in neonatal asthmatic rat by downregulating Notch signaling. Thus, oroxylin $A$ may be clinically beneficial in the management of asthma.
\end{abstract}

Keywords: Asthma, Oroxylin A, Cytokine, Neonatal, Notch signal route

\begin{abstract}
This is an Open Access article that uses a fund-ing model which does not charge readers or their institutions for access and distributed under the terms of the Creative Commons Attribution License (http://creativecommons.org/licenses/by/4.0) and the Budapest Open Access Initiative (http://www.budapestopenaccessinitiative.org/read), which permit unrestricted use, distribution, and reproduction in any medium, provided the original work is properly credited.

Tropical Journal of Pharmaceutical Research is indexed by Science Citation Index (SciSearch), Scopus, International Pharmaceutical Abstract, Chemical Abstracts, Embase, Index Copernicus, EBSCO, African Index Medicus, JournalSeek, Journal Citation Reports/Science Edition, Directory of Open Access Journals (DOAJ), African Journal Online, Bioline International, Open-J-Gate and Pharmacy Abstracts
\end{abstract}

\section{INTRODUCTION}

Asthma is an inflammatory disorder of the respiratory system due to hyper-responsiveness and mucus secretion which lead to narrowing of the airways [1]. Activation of $T$ lymphocytes contributes to the remodeling and inflammation of airways through the release of cytokines [2]. In asthma, mast cells release inflammatory mediators due to accentuated production of $\mathrm{IgE}$ by the Th2 cytokines [3]. However, Th2-induced immune response is suppressed due to secretion of IFN-g by Th1 cells. Asthma can be assessed by determining the stability of Th1/Th2 cytokine [4].

Studies have revealed that PI3K contributes to cell signaling, differentiation and proliferation [5]. The proliferation and survival of $T$ cells are influenced by the activation of PI3K enzymes 
present in large amounts in lung tissue. Reports suggest that inhibition of PI3K/AKT/mTOR pathway has beneficial effect on an inflammatory disorder such as asthma by ameliorating the activation of $T$ cells [6]. Moreover, activation and differentiation of $T$ cells are due to amelioration of the Notch signaling pathway [7]. Asthma leads to changes in Notch signaling, and inhibition of Notch signaling is involved in regulation of Th1 and Th2 cell-mediated pulmonary inflammation [8]. Thus, asthma could be treated by inhibiting the Notch signaling pathway.

Alternative medicine has shown potential effectiveness in the management of several chronic disorders, including asthma. Oroxylin $A$ is a 5,7-dihydroxy-6-methoxyflavone isolated from the roots of $S$. baicalensis [9]. It has been reported that oroxylin $A$ exerts neuroprotective, antitumor, anti-angiogenic and anti-inflammatory effects [10-12]. Moreover, oroxylin A reduced Nrf2 and NO levels and exerted anti-inflammatory properties in lipopolysaccharide-exposed mouse macrophage [13]. The present study determined the protective effect of oroxylin A against asthma in neonatal mice.

\section{EXPERIMENTAL}

\section{Animals}

BALB/c mice were kept under 12-h light/12-h dark cycle at $60 \pm 5 \%$ humidity and mean temperature of $24 \pm 3^{\circ} \mathrm{C}$. The mice were carefully monitored at the time of birth of pups on postnatal day 0 (P0). The protocols of the animal study were approved by the Institutional Animal Ethical Committee of Tonglu First People's Hospital, China (no. IAEC/TFPH/02/2018) and the given study followed the guidelines of Association for the Assessment and Accreditation of Laboratory Animal Care International (AAALAC) for experimentation and animal use [14].

\section{Animal grouping and treatment}

The pups were sensitized with OVA as per a previous report [15]. Postnatal day 12 (P12) pups were used in the investigation, and OVA (20 mg) was administered i.p. with $4 \mathrm{mg}$ of $\mathrm{Al}(\mathrm{OH})_{3}$ on days 0 and 14. Moreover, the pups were further exposed to $1 \%$ OVA from the $22^{\text {nd }}$ day to the $24^{\text {th }}$ day for the duration of $30 \mathrm{~min}$. The mice were assigned to four different groups: normal group, OVA group and two oroxylin $A$ groups given oroxylin $A$ at a dose of 2 or $10 \mathrm{mg} / \mathrm{kg}$ i.p. daily from day 0 to $14^{\text {th }}$ day, $2 \mathrm{~h}$ before the administration of OVA.

\section{Determination of hyper-responsiveness of airways}

Buxco's modular and invasive system was used to estimate airway hyper-responsiveness by exposing the animals to different concentrations of methacholine. The animals were anesthetized and kept in a ventilated body plethysmograph chamber after tracheotomy. Steady baseline airway pressure was monitored closely in each animal. Methacholine was administered using jet nebulizer at different concentrations i.e., 3.25, $6.25,12.5$, and $25 \mathrm{mg} / \mathrm{mL}$. Percentage of RI and Cdyn were determined, relative to PBS.

\section{Collection of bronchoalveolar lavage fluid}

The mice were sacrificed via cervical dislocation $24 \mathrm{~h}$ after the last administration of OVA, and tracheotomy was done. Bronchoalveolar lavage fluid (BALF) was isolated from the lung after instillation of ice-cold PBS. The collected sample of BALF was centrifuged at $4{ }^{\circ} \mathrm{C}$ for $10 \mathrm{~min}$ at $2000 \mathrm{rpm}$, and the supernatant was used for the estimation of cytokines.

\section{Determination of cytokines}

The levels of the cytokines IFN-g, IL-4, IL-5, IL-6 and IL-17 in the BALF ELISA were determined using ELISA kits as per the instructions of the kit manufacturers.

\section{Evaluation of levels of $\lg E$}

Levels of $\lg E$ in BALF and serum were estimated as per previously reported [16]. Serum was separated from blood collected from the retroorbital plexus of the mice. Then, OVA-coated microtiter plates were treated with anti-mouse $\operatorname{lgE}$ after treating the plates with serum and BALF. Avidin-horseradish peroxidase (HRP) solution was added to each well, and the absorbance of each well was read at $405 \mathrm{~nm}$.

\section{qRT-PCR}

TRIzol reagent was used to isolate total RNA from isolated CD4+ cells, as per the manufacturer's instructions. A reverse transcription kit was used to synthesize cDNA via reverse transcription from the RNA as per the manufacturer's instructions. The ABI Prism 7500 system and the SYBR green/fluorescein qPCR Master Mix kit were used to perform qRT-PCR. The qRTPCR conditions were as follows: $50{ }^{\circ} \mathrm{C}$ for $2 \mathrm{~min}$; $95^{\circ} \mathrm{C}$ for $10 \mathrm{~min}$; and 40 cycles of 95 ${ }^{\circ} \mathrm{C}$ for $30 \mathrm{sec}$ and $60^{\circ} \mathrm{C}$ for $30 \mathrm{sec}$. Analyses of mRNA expressions were performed using a TaqMan microRNA assay kit. The resulting data 
were analysed using the comparative Ct method $\left(2^{-\Delta \Delta C t}\right)$. The sequences of the primers used are shown in Table 1.

\section{Western blot assay}

Ice-cold radioimmunoprecipitation lysis buffer was used for extraction of total protein from the isolated CD4+ cells, while DC Protein Assay was used for the estimation of concentration of total protein. Equal amounts of protein were subjected to SDS-polyacrylamide gel electrophoresis and transferred to polyvinylidene difluoride membranes. The membranes were blocked by incubation with $5 \%$ fresh non-fat dry milk solution, followed by incubation overnight at $4{ }^{\circ} \mathrm{C}$ with primary antibodies for Akt, p-Akt, PI3K, pPI3K, Notch1, NICD, PTEN, NF-kB and $\beta$-actin. Thereafter, the membranes were incubated with HRP-linked secondary antibody for $60 \mathrm{~min}$ at room temperature. Chemiluminescence was used to enhance the blots, while ImageLab software was used to perform densitometric analysis.

\section{Statistical analysis}

All data are expressed as mean \pm standard error of the mean (SEM. Statistical analysis was done with one-way analysis of variance (ANOVA). Post-hoc comparisons of means were carried out with Dunnett's post-hoc test using GraphPad Prism software (ver. 6.1; San Diego, CA, USA). Values of $p<0.05$ were considered to indicate statistical significance.

\section{RESULTS}

\section{Oroxylin A attenuated airway hyper- responsiveness}

The effect of oroxylin A on lung function was determined by assessing lung compliance and airway resistance in OVA-challenged mice. The results are shown in Figure 1. Percentage of lung compliance was reduced with increase in the concentration of methacholine in OVA group, when compared to normal mice. However, treatment with oroxylin $A$ reversed the reduction in lung compliance in methacholine-treated OVAchallenged mice, relative to OVA group. Moreover, percentage of airway resistance was enhanced with increase in the concentration of methacholine in OVA group, when compared to normal group of mice. In contrast, oroxylin A treatment attenuated the enhancement in percentage of airway resistance in methacholinetreated OVA-challenged mice.
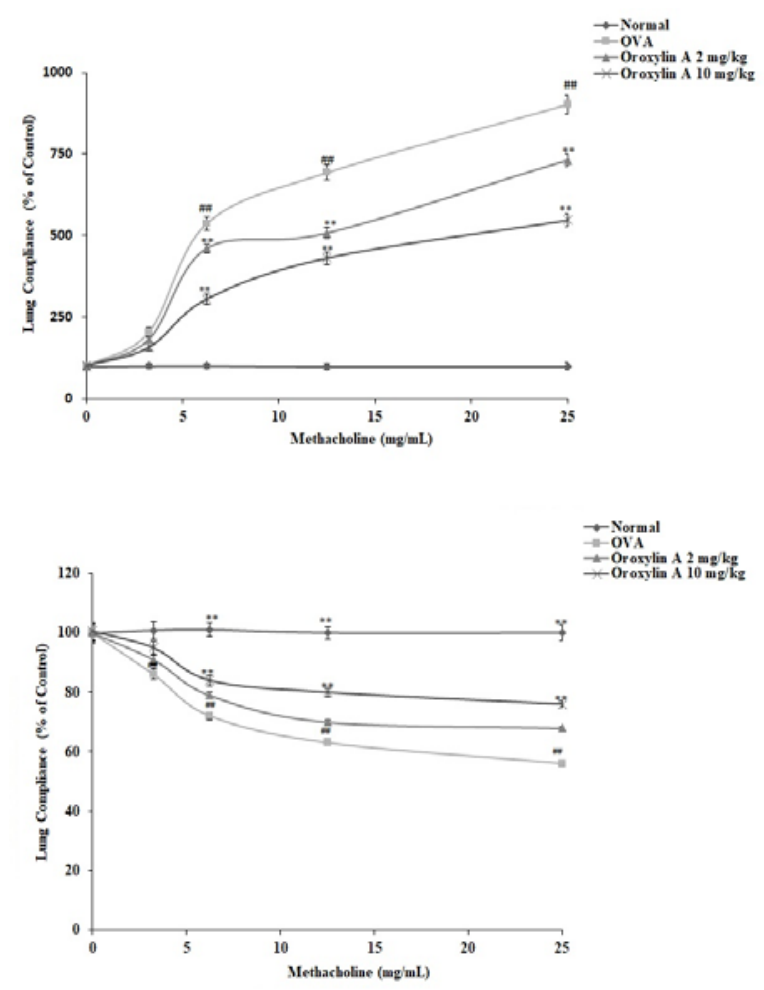

Figure 1: Effect of oroxylin $A$ on lung compliance and airway resistance in methacholine-treated, OVAchallenged mice. Data are shown as mean \pm SEM $(n=$ 12); ${ }^{\#} p<0.01$, vs normal group; ${ }^{* *} p<0.01$, vs OVA group

\section{Oroxylin A reduced the levels of cytokines}

Figure 2 shows that there were increases in the concentrations of IL-4, IL-5, IL-13 and IL-17, while the concentration of IFN-g was decreased in the BALF of the OVA group, when compared with the normal group of mice. However, oroxylin A treatment markedly reduced the levels of IL-4, IL-5, IL-13 and IL-17, and increased the level of IFN-g in the BALF, when compared with the OVA group of mice.

Table 1: Primers used in PCR

\begin{tabular}{lll}
\hline Primers & Forward & Backward \\
\hline Notch 1 & 5'-GGTGAACTGCTCTGAGGAGATC-3' & 5'-GGATTGCAGTCGTCCACGTTGA-3' \\
NICD & 5'-GTGTGTGTCAATGGCTGGAC-3' & 5'-GTGACACAGGAGGCCAGTCT-3' \\
Jagged 1 & 5'-ATCGTGCTGCCTTTCAGTTT-3' & 5'-GGTCACGCGGATCTGATACT-3' \\
ß-actin & 5'-CACCATTGGCAATGAGCGGTTC-3' & 5'-AGGTCTTTGCGGATGTCCACGT-3' \\
\hline
\end{tabular}




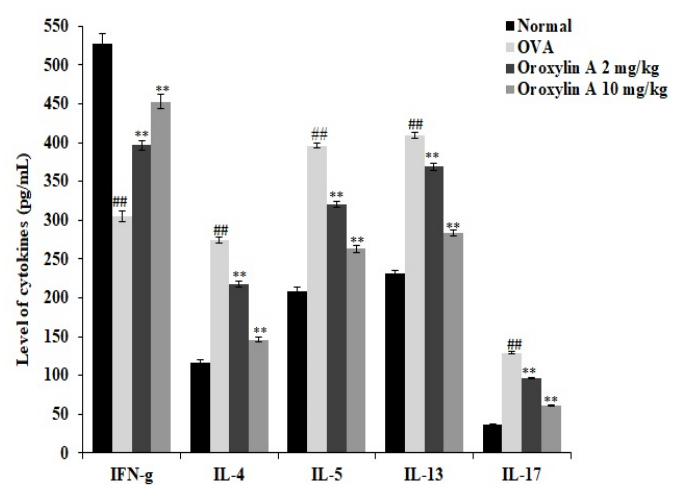

Figure 2: Effect of oroxylin A on the levels of cytokines in the BALF of OVA-challenged mice. Data are presented as mean $\pm \operatorname{SEM}(\mathrm{n}=12) ;{ }^{\#} p<0.01$, vs normal group; ${ }^{* *} p<0.01$, vs OVA group

\section{Oroxylin A lowered the level of IgE}

The IgE levels in serum and BALF of oroxylin Atreated, OVA-challenged mice are shown in Figure 3. There were increases in serum and BALF levels of IgE in the OVA group of mice, relative to normal group. However, oroxylin treatment reduced the serum and BALF levels of $\mathrm{IgE}$, when compared to the OVA group of mice.

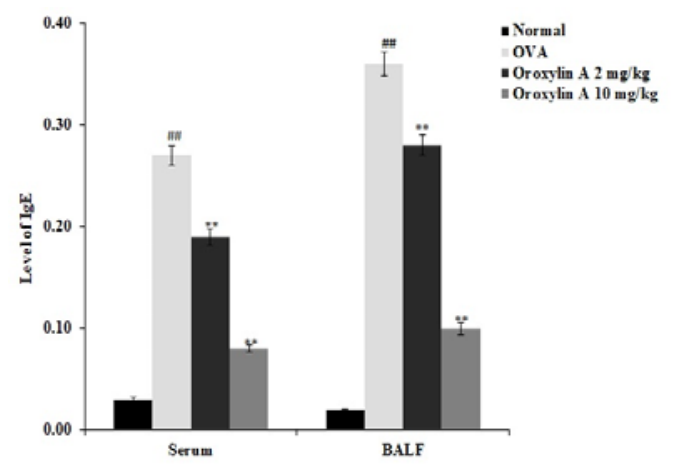

Figure 3: Effect of oroxylin $A$ on the levels of IgE in BALF and serum of OVA-challenged mice. Data are shown as mean \pm SEM $(n=12)$; ${ }^{\#} p<0.01$, vs normal group; ${ }^{* *} p<0.01$, vs OVA group

\section{Oroxylin A reduced mRNA expressions of Notch1, Jagged1 and NICD}

Figure 4 shows the mRNA expression levels of Notch1, Jagged1 and NICD in the BALF of oroxylin A-treated, OVA-challenged mice. There were increases in the mRNA expressions of Notch1, Jagged1 and NICD in the BALF of the OVA group, when compared with the normal group of mice. However, treatment with oroxylin A reduced the mRNA expressions of Notch1, Jagged1 and NICD in the BALF of OVAchallenged mice.

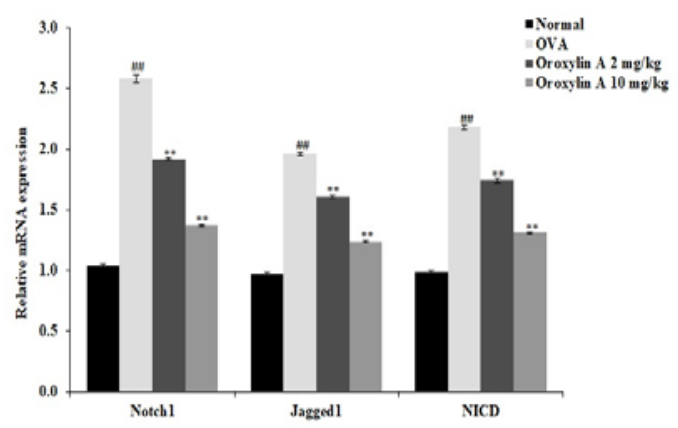

Figure 4: Effect of oroxylin A on the mRNA expression levels of Notch1, Jagged1 and NICD in the BALF of OVA-challenged mice. Results are shown as mean \pm SEM $(\mathrm{n}=12)$; ${ }^{\# \#} p<0.01$, vs normal group; ${ }^{* *} p<0.01$, vs OVA group.

\section{Oroxylin A downregulated the expressions of Akt, PI3K, Notch1 and PTEN proteins}

There were increases in the protein expressions of Notch1, PI3K and Akt, and decrease in the protein expression of PTEN in the BALF of OVA group, when compared to normal group of mice (Figure 5). However, treatment with oroxylin A reversed the altered protein expressions of Notch1, Akt, PI3K and PTEN in the BALF of OVA-challenged mice.

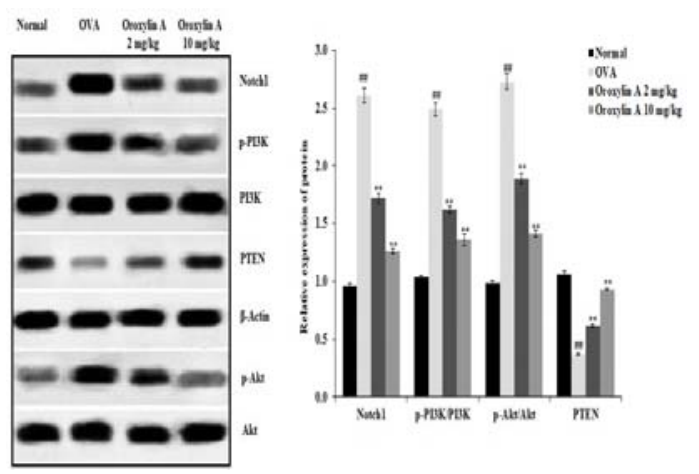

Figure 5: Effect of oroxylin $A$ on the protein expressions of Notch1, Akt, PI3K and PTEN in the BALF of OVA-challenged mice. Data are shown as mean \pm SEM $(n=12) ;{ }^{\# \#} p<0.01$, vs normal group; ${ }^{* *} p$ $<0.01$, vs OVA group

\section{DISCUSSION}

Asthma is a pathological condition due to excessive secretion of mucus and narrowing of airways, leading to difficulty in breathing [17]. The management of asthma is still a medical challenge. Thus, there is need to develop alternative medicines for its treatment. The present study evaluated the protective effect of 
oroxylin A against asthma by estimating lung function and levels of cytokines and IgE in OVAchallenged mice. Moreover, western blot assay and qRT-PCR studies were carried out for determination of the effect of oroxylin A on Notch signaling in OVA-challenged mice.

It has been postulated that in the pathogenesis of asthma, narrowing of the airway and hypersecretion of mucus occur due to increased levels of cytokines which are responsible for enhancement of production of $\lg E$ [1]. The results of the present study are in line with this hypothesis, since the levels of cytokines and IgE were markedly higher in OVA-challenged mice than in normal mice. The increased production of $\operatorname{lgE}$ triggered the release of inflammatory mediators (from mast cells) which are responsible for mucus secretion and narrowing of airways. It has been reported that drugs which reduce the production of $\operatorname{lgE}$ and inflammatory cytokines showed promising beneficial effects in the management of asthma [18]. The results of the present study indicate that oroxylin $A$ reduced the levels of cytokines and $\lg E$ in the serum and BALF of OVA-challenged mice, when compared to OVA group. Moreover, oroxylin A improved lung function by attenuating the altered percentage of lung compliance and airway resistance in OVA-challenged mice.

The Notch and PI3K pathways are involved in the proliferation of $\mathrm{T}$ cells. In asthma, the expressions of Notch1 receptor and its ligand (Jagged1) are upregulated in BALF [19]. The ligand of Notch1 receptor binds to its receptor and initiates Notch1 signaling, leading to cleavage of NICD [20]. The Notch signaling pathway contributes to the development of asthma. In this study, oroxylin A reversed the altered protein expressions of Notch1, Jagged1, Akt, PI3K, PTEN and NICD in isolated CD4+ cells from OVA-challenged mice.

\section{CONCLUSION}

The findings of this study show that oroxylin A improves lung function and reduces the levels of cytokines in neonatal asthmatic rat by downregulating Notch signaling pathway. Thus, oroxylin A may be clinically beneficial in the management of asthma.

\section{DECLARATIONS}

\section{Acknowledgement}

The authors of this manuscript are thankful to Tonglu First People's Hospital, China for providing the necessary facility to conduct this work.

\section{Conflict of interest}

No conflict of interest is associated with this work.

\section{Contribution of authors}

We declare that this work was done by the authors named in this article and all liabilities pertaining to claims relating to the content of this article will be borne by the authors. Ping Hua performed the experimental work and collected the data of presented work. Wei Wang and Lina Xiao contributes for statistical analysis and writing of manuscript. Hongjie Tao designed and supervised the study and corrected the manuscript.

\section{Open Access}

This is an Open Access article that uses a funding model which does not charge readers or their institutions for access and distributed under the terms of the Creative Commons Attribution License (http://creativecommons.org/licenses/by/ 4.0) and the Budapest Open Access Initiative (http://www.budapestopenaccessinitiative.org/rea d), which permit unrestricted use, distribution, and reproduction in any medium, provided the original work is properly credited.

\section{REFERENCES}

1. Kudo M, Ishigatsubo Y, Aoki I. Pathology of asthma. Front Microbiol 2013; 4: 263.

2. Wang $Y, X u$ J, Meng $Y$, Adcock IM, Yao X. Role of inflammatory cells in airway remodeling in COPD. Int $J$ Chron Obstruct Pulmon Dis 2018; 13: 3341-3348.

3. Hall S, Agrawal DK. Key mediators in the immunopathogenesis of allergic asthma. Int Immunopharmacol 2014; 23(1): 316-329.

4. Hansen G, Berry G, DeKruyff RH, Umetsu DT. Allergenspecific Th1 cells fail to counterbalance Th2 cell-induced airway hyperreactivity but cause severe airway inflammation. J Clin Invest 1999; 103(2): 175-183.

5. Jellusova J, Rickert RC. The PI3K pathway in B cell metabolism. Crit Rev Biochem Mol Biol 2016; 51(5): 359-378.

6. Choi YH, Jin GY, Li LC, Yan GH. Inhibition of protein kinase $C$ delta attenuates allergic airway inflammation through suppression of PI3K/Akt/mTOR/HIF-1 alpha/VEGF pathway. PLoS One 2013; 8(11): e81773.

7. Mochizuki K, He S, Zhang Y. Notch and inflammatory Tcell response: new developments and challenges. Immunother 2011; 3(11): 1353-1366.

Trop J Pharm Res, June 2021; 20(6): 1149 
8. Zong $D$, Ouyang $R, L i J$, Chen $Y$, Chen P. Notch signaling in lung diseases: focus on Notch1 and Notch3. Ther Adv Respir Dis 2016; 10(5): 468-484.

9. Huen MS, Leung JW, Ng W, Lui WS, Chan MN, Wong JT, Xue H. 5,7-Dihydroxy-6-methoxyflavone, a benzodiazepine site ligand isolated from Scutellaria baicalensis Georgi, with selective antagonistic properties. Biochem Pharmacol 2003; 66(1): 125-132.

10. Sun $X$, Chang $X$, Wang $Y, X U$, Cao $X$. Oroxylin $A$ Suppresses the Cell Proliferation, Migration, and EMT via NF-kB Signaling Pathway in Human Breast Cancer Cells. Biomed Res Int 2019; 2019: 9241769.

11. Ye M, Wang Q, Zhang W, Li Z, Wang Y, Hu R. Oroxylin A exerts anti-inflammatory activity on lipopolysaccharideinduced mouse macrophage via Nrf2/ARE activation. Biochem Cell Biol 2014; 92(5): 337-348.

12. Jeon SJ, Bak H, Seo J, Han SM, Lee SH, Han SH, Kwon $\mathrm{KJ}$, Ryu JH, Cheong JH, Ko KH, Yang SI, Choi JW, Park SH, Shin CY. Oroxylin A Induces BDNF Expression on Cortical Neurons through Adenosine A2A Receptor Stimulation: A Possible Role in Neuroprotection. Biomol Ther (Seoul) 2012; 20(1): 2735.

13. Chen Y, Yang L, Lee TJ. Oroxylin A inhibition of lipopolysaccharide-induced iNOS and COX-2 gene expression via suppression of nuclear factor-kappaB activation. Biochem Pharmacol 2000; 59(11): 1445 1457.

14. Guide for the Care and Use of Laboratory Animals: Eighth Edition Committee for the Update of the Guide for the Care and Use of Laboratory Animals; National Research Council. 2010; ISBN: 0-309-15401-4.

15. Chapman TJ, Emo JA, Knowlden SA, Rezaee F, Georas $S N$. Pre-existing tolerance shapes the outcome of mucosal allergen sensitization in a murine model of asthma. J Immunol. 2013; 191(8): 4423-4430.

16. Sandeep T, Roopakala MS, Silvia CR, Chandrashekara $S$, Rao M. Evaluation of serum immunoglobulin E levels in bronchial asthma. Lung India 2010; 27(3): 138-140.

17. Evans CM, Kim K, Tuvim MJ, Dickey BF. Mucus hypersecretion in asthma: causes and effects. Curr Opin Pulm Med 2009; 15(1): 4-11.

18. Zdanowicz MM. Pharmacotherapy of asthma. Am J Pharm Educ 2007; 71(5): 98.

19. Huang MT, Chen YL, Lien Cl, Liu WL, Hsu LC, Yagita H, Chiang BL. Notch Ligand DLL4 Alleviates Allergic Airway Inflammation via Induction of a Homeostatic Regulatory Pathway. Sci Rep 2017; 7: 43535.

20. Chillakuri CR, Sheppard D, Lea SM, Handford PA. Notch receptor-ligand binding and activation: insights from molecular studies. Semin Cell Dev Biol 2012; 23(4): 421-428. 